Brazilian Journal

of Chemical

ISSN 0104-6632

Engineering

\title{
EFFECT OF CONTINUOUS CRYSTALLIZER PERFORMANCE ON STRUVITE CRYSTALS PRODUCED IN REACTION CRYSTALLIZATION FROM SOLUTIONS CONTAINING PHOSPHATE(V) AND ZINC(II) IONS
}

\author{
N. Hutnik ${ }^{1}$, B. Wierzbowska ${ }^{1}$, K. Piotrowski ${ }^{2 *}$ and A. Matynia ${ }^{1}$ \\ ${ }^{1}$ Wroclaw University of Technology, Faculty of Chemistry, Wybrzeze Wyspianskiego \\ 27, 50-370 Wroclaw, Poland. Phone: (+ 48 71) 320-3497; Fax: (+ 48 71) 328-0425 \\ E-mail: nina.hutnik@pwr.edu.pl; boguslawa.wierzbowska@pwr.edu.pl; andrzej.matynia@pwr.edu.pl \\ ${ }^{2}$ Silesian University of Technology, Department of Chemical Engineering and Process Design, \\ M. Strzody 7, 44-101 Gliwice, Poland. Phone/Fax: (+ 48 32) 237-1461 \\ E-mail: krzysztof.piotrowski@polsl.pl
}

(Submitted: March 24, 2014 ; Revised: March 31, 2015 ; Accepted: April 1, 2015)

\begin{abstract}
Continuous reaction crystallization of struvite from aqueous solutions containing phosphate(V) (1.0 mass \%) and zinc(II) ions (from 0.1 to $2.0 \mathrm{mg} \mathrm{kg}^{-1}$ ) in a continuous DT MSMPR crystallizer was investigated. The influence of $\mathrm{pH}(9-11)$ and mean residence time $(900-3600 \mathrm{~s})$ on the product characteristics and its chemical composition was tested. Struvite crystals of mean size 22-41 $\mu \mathrm{m}$ were produced. An increase in $\mathrm{Zn}^{2+}$ concentration decreased the mean crystal size and homogeneity. An elevation of the $\mathrm{pH}$ also decreased the struvite crystal size. Augmenting the mean residence time influenced product quality advantageously. Coexistence of struvite and $\mathrm{Zn}(\mathrm{OH})_{2}$ in the product was confirmed analytically. Keywords: Struvite; Phosphate(V) ions; Zinc(II) ions; Continuous reaction crystallization; Crystal product quality; Phosphorus recycling.
\end{abstract}

\section{INTRODUCTION}

Recovery of phosphate $(\mathrm{V})$ ions from wastewaters by reaction crystallization of struvite $\mathrm{MgNH}_{4} \mathrm{PO}_{4} \cdot 6 \mathrm{H}_{2} \mathrm{O}$, is a complex technological challenge (Doyle and Parsons, 2004; Le Corre et al., 2009; Rahman et al., 2014). The course of the process and its results are affected by many process variables (e.g., feed solution composition, component concentrations) (Doyle and Parsons, 2002; Le Corre et al., 2009; Kozik et al., 2013; Hutnik et al., 2013a; Karabegovic et al., 2013; Rahman et al., 2014), technological aspects (e.g., $\mathrm{pH}$, mean residence time of the suspension in the crystallizer, molar ratio of substrates) (Parsons, 2001; Matynia et al., 2006; Le Corre et al., 2007a;
Kozik et al., 2014a) and even constructional parameters (e.g. mixing and/or circulation method, mixing intensity and efficiency) (Ali and Schneider, 2006; Bhuiyan et al., 2008; Le Corre et al., 2009; Marti et al., 2010; Mazienczuk et al., 2012). Struvite precipitates in supersaturated aqueous solutions of phosphate $(\mathrm{V})$, magnesium and ammonium ions, within the $\mathrm{pH}$ range of $7-11$ (solubility product $\mathrm{pK}_{\mathrm{sp}}=9.4-$ 13.36) (Doyle and Parsons, 2002; Bhuiyan et al., 2007). With a $\mathrm{pH}$ increase, struvite solubility decreases with a minimal $\mathrm{K}_{\mathrm{sp}}$ value corresponds to $\mathrm{pH}$ 10.3 (Ohlinger et al., 1998) or 10.7 (Snoeyink and Jenkins, 1980); thus its precipitation potential grows (Parsons, 2001). Also the induction time necessary for initiation of the batch nucleation process of stru-

*To whom correspondence should be addressed 
vite shortens (Bouropoulos and Koutsoukos, 2000; Kofina and Koutsoukos, 2005; Le Corre et al. 2007b).

The final results of the struvite reaction crystallization process strongly depend on the chemical composition of wastewater. Impurities present in wastewater, mainly metal ions, but also sulphates(VI), nitrates(V), carbonates, etc., can influence struvite nucleation and its crystal growth, shape and agglomeration, as well as chemical composition of the final product (including co-precipitated sparingly soluble hydroxides or phosphates(V) of selected metal impurities) (Hutnik et al., 2013a). Catalyzing or inhibiting effects of individual ionic impurities (Hutnik et al., 2011a) depend on the struvite reaction crystallization mode, crystallizer type and the operational parameters assumed (e.g., recovery of struvite in the presence of calcium ions in a batch crystallizer (Le Corre et al., 2005) and in a continuous crystallizer (Hutnik et al., 2011b)).

The complex influence of various factors requires fully controlled conditions for struvite production and partly purifying wastewater systems (Le Corre et al., 2009). Recovered solid product should be of good quality. Struvite crystals should be prismatic or needle-like, homogeneous in size and possibly large. The product should not contain too large an amount of impurities co-precipitated from the wastewater (Hutnik et al., 2013a). Such a solid product can be of practical use, e.g., as mineral fertilizer (NPMg) in agriculture (de-Bashan and Bashan, 2004; Latifian et al., 2012).
Experimental research results concerning continuous reaction crystallization of struvite from synthetic wastewater containing 1.0 mass $\% \mathrm{PO}_{4}{ }^{3-}$ ions $\left(\left[\mathrm{PO}_{4}{ }^{3-}\right]_{\mathrm{RM}}\right.$ ) and from 0.1 to $2.0 \mathrm{mg} \mathrm{kg}^{-1}$ of $\mathrm{Zn}^{2+}$ ions $\left(\left[\mathrm{Zn}^{2+}\right]_{\mathrm{RM}}\right)$ are presented and discussed. Zinc(II) ions can be found, e.g., in industrial wastewaters and in swine wastewaters (Hutnik et al., 2013a; Rahman et $a l ., 2014)$. Product crystal size distribution and statistical parameters of this distribution $\left(\mathrm{L}_{\mathrm{m}}, \mathrm{L}_{50}, \mathrm{~L}_{\mathrm{d}}, \mathrm{CV}\right)$ were determined. Crystal shape (as $\mathrm{L}_{\mathrm{a}} / \mathrm{L}_{\mathrm{b}}$ ) and agglomeration effects were evaluated and estimated. Zinc(II) content in the mother liquor and in the solid product was determined with analytical methods. Process effectiveness, defined as the final concentration of phosphate $(\mathrm{V})$ ions in a postprocessed mother solution $\left(\left[\mathrm{PO}_{4}{ }^{3-}\right]_{\mathrm{ML}}\right)$, was also evaluated.

\section{EXPERIMENTAL}

\section{Materials and Methods}

The scheme of laboratory system for experimental investigation of the continuous struvite reaction crystallization process in the presence of zinc(II) ions is presented in Figure 1. The DT MSMPR (Draft Tube, Mixed Suspension Mixed Product Removal) type crystallizer with internal circulation of the suspension driven by a propeller mixer was used (Mullin, 1993).

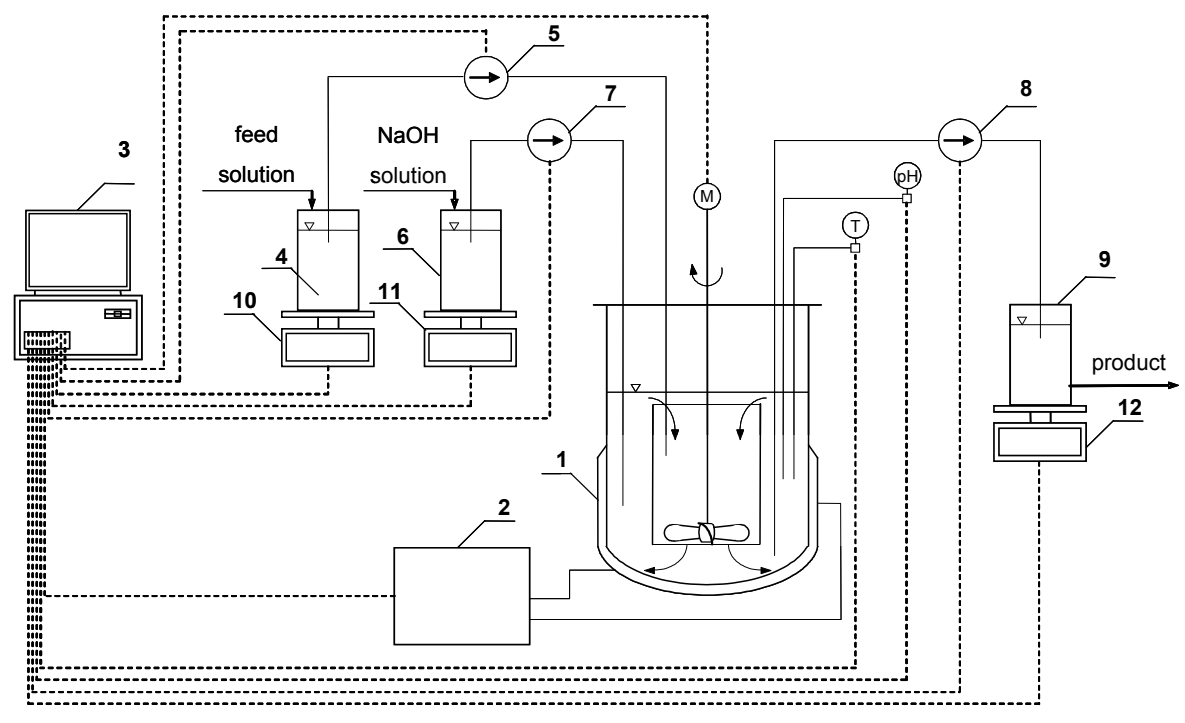

Figure 1: Schematic diagram of the experimental plant. 1 - DT MSMPR type crystallizer with internal circulation of suspension, 2 - thermostat, 3 - PC computer, 4 - feed reservoir: aqueous solution of $\mathrm{MgCl}_{2}, \mathrm{NH}_{4} \mathrm{H}_{2} \mathrm{PO}_{4}$ and $\mathrm{ZnCl}_{2}$, 5 - feed proportioner (pump), 6 - alkalinity agent tank: aqueous solution of $\mathrm{NaOH}, 7$ - proportioner (pump) of $\mathrm{NaOH}$ solution, 8 - receiver (pump) of product crystal suspension from the crystallizer tank, 9 - storage tank of the product crystal suspension, $10,11,12$ - electronic balances, $\mathrm{M}$ - stirrer speed control/adjustment, $\mathrm{pH}$ - alkaline/acid reaction control/adjustment, $\mathrm{T}$ - temperature control/adjustment. 
Stirring, control and acquisition of measurement data were done with the use of a PC computer. For precise performance and control of the experimental setup in a stable steady state, IKA labworldsoft and BioScadalab programmes were used. The crystallizer working volume was $0.6 \mathrm{dm}^{3}$. It was a glass cylindrical tank (D $120 \mathrm{~mm}, \mathrm{H} 123 \mathrm{~mm}$ ), equipped in a bottom part with an external heating/cooling coil (thermostated via an external water circulation loop), providing isothermal process conditions. In the central axis of the apparatus a cylindrical circulation profile (Draft Tube, DT, $\mathrm{d}_{\mathrm{dt}} 57 \mathrm{~mm}, \mathrm{~h}_{\mathrm{dt}} 53 \mathrm{~mm}$ ) was installed, inside of which three-paddle propeller stirrer $\left(\mathrm{d}_{\mathrm{m}} 55 \mathrm{~mm}\right)$ operated. The inlet ports for the raw materials mixture and alkalising solution delivery, together with the port for isokinetic removal of product crystal suspension are marked in Figure 1. The crystallizer was continuously provided with a feed prepared earlier in an external mixer with chemically pure substances (magnesium chloride, $\mathrm{MgCl}_{2} \cdot 6 \mathrm{H}_{2} \mathrm{O}$, ammonium dihydrogenphosphate( $(\mathrm{V}), \mathrm{NH}_{4} \mathrm{H}_{2} \mathrm{PO}_{4}$, zinc(II) chloride, $\mathrm{ZnCl}_{2}$, p.a. POCh, Gliwice, Poland) and deionised water (Barnstead - NANOpure DIamond). This mixture was introducing into the DT subvolume (mixer speed: $6.6( \pm 0.1) \mathrm{s}^{-1}$; suspension movement to the bottom). Between the crystallizer body and DT element (suspension movement - to the top) an aqueous solution of sodium hydroxide ( 20 mass $\%$ ) was dosed in proportions providing the computer-controlled $\mathrm{pH}$ of the struvite reaction crystallization process environment in which zinc(II) ions also coprecipitated as $\mathrm{Zn}(\mathrm{OH})_{2}$.

The process temperature was $298( \pm 0.2) \mathrm{K}$. Tests were run under stoichiometric conditions: molar ratio of reagents in the feed $\mathrm{PO}_{4}{ }^{3-}: \mathrm{Mg}^{2+}: \mathrm{NH}_{4}{ }^{+}=1: 1: 1$. The feed concentration of phosphate(V) ions was 1.0 mass $\%$, magnesium ions 0.256 mass $\%$, and ammonium ions 0.190 mass \%. The concentration of zinc(II) ions was changed within the range of $0.1-$ $2.0 \mathrm{mg} \mathrm{kg}^{-1}$. Continuous reaction crystallization of struvite was carried out at $\mathrm{pH} 9( \pm 0.1)$ providing a mean residence time of suspension in the crystallizer $\tau=900 \mathrm{~s}( \pm 20 \mathrm{~s})$. For a feed concentration of zinc(II) ions $\left[\mathrm{Zn}^{2+}\right]_{\mathrm{RM}}$ of $0.2 \mathrm{mg} \mathrm{kg}^{-1}$, the measurements at $\mathrm{pH}$ 10 and 11 , as well as for $\tau=1800$ and $3600 \mathrm{~s}$, were also done. After establishing and stabilisation of the assumed parameter values in the crystallizer (initial $5 \tau$ ), the process was run in a steady state through the next $5 \tau$. After this time the whole crystallizer content was transferred to a vacuum filter. Product crystals were not washed. Using the appropriate analytical methods, the solid phase content in the product crys- tal suspension $\left(\mathrm{M}_{\mathrm{T}}\right)$, the chemical composition of the mother solution and solid phase (plasma emission spectrometer ICP-AES CPU 7000, spectrometer IR PU9712, atomic absorption spectrometer iCE 3000, spectrophotometer UV-Vis Evolution 300), the product crystal size distribution (solid particle laser analyser Coulter LS-230, Beckman Coulter LS 13-320) and the crystal shape (scanning electron microscope JEOL JSM 5800LV) were determined. Measurement accuracy of the process data in the continuous plant used was estimated to be ca. $\pm 10 \%$.

For solid phase analysis, an X-ray fluorescence spectrometer PANalytical Magi'X PW2424 (phosphorus and zinc) was used. Phase identification and quantification in the product was done with an X-ray diffractometer PANalytical XPERT PRO MPD and the Rietveld method.

Feed composition, $\mathrm{pH}$ of the mother solution and the mean residence time of the suspension in the crystallizer were assumed to be the process variables. The supersaturation value corresponding to the crystallizer inlet conditions (in a form of the saturation index $\left.\mathrm{SI}=\log (\mathrm{IAP})-\log \left(\mathrm{K}_{\mathrm{sp}}\right)\right)$ was calculated with the use of Visual MINTEQ ver. 3.1 professional software (Gustafsson, 2014) - Tables 1 and 2. The majority of the published works about nucleation and growth of struvite crystals with supersaturation control (Kofina and Koutsoukos, 2005; Ali and Schneider, 2006) assume most often that $\mathrm{pK}_{\mathrm{sp}}=13.26(\mathrm{Oh}-$ linger et al., 1998). For this $\mathrm{pK}_{\mathrm{sp}}$ the equilibrium concentration of phosphate $(\mathrm{V})$ ions is $3.6 \mathrm{mg} \mathrm{kg}^{-1}$. In reality, however, this value is unknown since it depends in a complex way on many process parameters (e.g., solution composition, component concentrations, $\mathrm{pH}$, mixing intensity and efficiency, as well as even on constructional parameters of the crystallizer) (Le Corre et al., 2009). Clear-cut determination of the metastable zone width and working supersaturation in a real struvite continuous reaction crystallization system is thus a complex problem (Ali and Schneider, 2006). The SI values presented in Tables 1 and 2 should thus be regarded as estimates. On the other hand, it is known that, in a continuous crystallizer, for constant feed composition and other operational parameters (mixing intensity), the working supersaturation can be indirectly represented by an unequivocally correlated mean residence time of the suspension, $\tau$ (Mullin, 1993). Precise experimental determination of the interaction between decisive process parameters (feed composition, $\mathrm{pH}, \tau$, etc.) and the results (e.g., crystal size distributions) thus becomes possible and more credible (Mersmann, 1995). 
RESULTS AND DISCUSSION

\section{Crystal Size Distribution}

Properly shaped struvite crystals whose mean size $\mathrm{L}_{\mathrm{m}}$ varied from 22 up to $41 \mu \mathrm{m}$ were produced, depending on the combination of decisive process parameter values (feed composition $-\mathrm{pH}-\tau$ ). Statistical parameters of the corresponding crystal size distributions (CSDs) are presented in Table 1. The table shows that the presence of zinc(II) ions influenced both the struvite crystal size and homogeneity disadvantageously (tests No. 1-5 in Table 1).

With the increase in $\mathrm{Zn}^{2+}$ ion concentration in a feed from 0.1 to $2.0 \mathrm{mg} \mathrm{kg}^{-1}$, the mean crystal size $\mathrm{L}_{\mathrm{m}}$ decreased from 34.0 to $23.1 \mu \mathrm{m}$ (thus by $35 \%$ ). Median crystal size $\mathrm{L}_{50}$ decreased by ca. $39 \%$ (from 26.6 to $16.1 \mu \mathrm{m})$. Homogeneity of the product crystal population could be generally evaluated as unsatisfactory. With the increase in zinc(II) ion concentration in the feed the crystal size coefficient of variation $\mathrm{CV}$ systematically increased from 82.7 up to $92.1 \%$. Decrease of the mean size $\mathrm{L}_{m}$ of the product crystals with the increase in zinc(II) ion concentration in the process is connected with a general increase in the number of the smallest struvite crystals in the solid product population. As a result, the dominant crystal size shifted towards smaller values: $L_{d} 36.9 \rightarrow 19.9 \mu \mathrm{m}$ for
$\left[\mathrm{Zn}^{2+}\right]_{\mathrm{RM}} 0.1 \rightarrow 2.0 \mathrm{mg} \mathrm{kg}^{-1}$. Simultaneously the number and size of the largest crystals decreased. The largest size of struvite particles produced in the presence of $0.2 \mathrm{mg} \mathrm{Zn}^{2+} \mathrm{kg}^{-1}$ was $160 \mu \mathrm{m}$, whereas in the

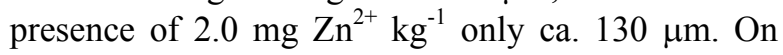
contrary, the fraction of the smallest-size particles increased. For $\left[\mathrm{Zn}^{2+}\right]_{\mathrm{RM}} 0.2 \mathrm{mg} \mathrm{kg}^{-1}$ the crystal fraction of sizes below $5 \mu \mathrm{m}$ in the product was $12.3 \%$, while in the case of $2.0 \mathrm{mg} \mathrm{Zn} \mathrm{Zn}^{2+} \mathrm{kg}^{-1}$ this fraction enlarged up to $17.3 \%$, and thus increased by ca. $40 \%$. This trend is clearly visible in Figure 2, which presents exemplary volumetric (mass) size distributions of struvite crystals produced in the presence of 0.2 (Figure 2(a)) and 2.0 (Figure 2(b)) $\mathrm{mg} \mathrm{Zn}^{2+} \mathrm{kg}^{-1}$ in the feed (pH 9, $\tau 900 \mathrm{~s}$ ).

On this basis one can conclude that zinc(II) ions favoured struvite nucleation, simultaneously partly confining its crystal growth. It can also be directly evaluated visually by analysing scanning electron microscope images of product crystal samples (Figure 3(a), (b)), for which the corresponding size distributions are presented in Figure 2(a), (b).

Differences in size and shape of struvite crystals are clearly visible $\left(\mathrm{L}_{\mathrm{m}} 31.4\right.$ and $23.1 \mu \mathrm{m}$, appropriately). Moreover, one can notice less than moderate agglomeration effects within the large struvite crystals.

With the increase in $\mathrm{pH}$ of the struvite reaction crystallization environment, the product crystal sizes decreased (tests No. 2, 6 and 7 in Table 1).

Table 1: Effect of $\mathrm{Zn}^{2+}$ ion concentration in the feed, $\mathrm{pH}$ and mean residence time $\tau$ of the suspension in the DT MSMPR crystallizer on crystal product characteristics. Concentration of phosphate $(V)$ ions in the feed: $\left[\mathrm{PO}_{4}{ }^{3-}\right]_{\mathrm{RM}}=1.0$ mass $\%$, molar proportion of substrate ions in a feed: $\mathrm{PO}_{4}{ }^{3-}: \mathrm{Mg}^{2+}: \mathrm{NH}_{4}{ }^{+}=1: 1: 1$. Reaction crystallization process temperature: $298 \pm 0.2 \mathrm{~K}$.

\begin{tabular}{|c|c|c|c|c|c|c|c|c|c|c|c|c|}
\hline \multirow{2}{*}{ No. } & \multicolumn{4}{|c|}{$\begin{array}{c}\text { Process } \\
\text { parameters }\end{array}$} & \multicolumn{2}{|c|}{$\begin{array}{c}\text { Suspension in a } \\
\text { crystallizer }\end{array}$} & \multicolumn{5}{|c|}{$\begin{array}{c}\text { Struvite crystals } \\
\text { characteristics }^{\mathrm{a}}\end{array}$} & \multirow{2}{*}{$\frac{\text { Product }^{\mathrm{a}}}{\left[\mathrm{Zn}^{2+}\right]}$} \\
\hline & $\begin{array}{l}{\left[\mathrm{Zn}^{2+}\right]_{\mathrm{RM}}} \\
\left(\mathrm{mg} \mathrm{kg}^{-1}\right)\end{array}$ & pH & $\begin{array}{c}\tau \\
(\mathbf{s})\end{array}$ & SI & $\begin{array}{c}M_{T} \\
\left(\mathrm{~kg} \mathrm{~m}^{-3}\right)\end{array}$ & $\begin{array}{l}{\left[\mathrm{PO}_{4}{ }^{3-}\right]_{\mathrm{ML}}} \\
\left(\mathrm{mg} \mathrm{kg}^{-1}\right)\end{array}$ & $\begin{array}{c}\mathbf{L}_{\mathbf{m}} \\
(\mu \mathbf{m})\end{array}$ & $\begin{array}{c}\mathbf{L}_{50} \\
(\mu \mathrm{m})\end{array}$ & $\begin{array}{c}\mathbf{L}_{\mathbf{d}} \\
(\mu \mathbf{m})\end{array}$ & $\begin{array}{l}\text { CV } \\
(\%)\end{array}$ & $\mathbf{L}_{\mathbf{a}} / \mathbf{L}_{\mathbf{b}}$ & \\
\hline 1 & 0.1 & 9 & 900 & 4.625 & 23.6 & 146 & 34.0 & 26.6 & 36.9 & 82.7 & 8.4 & $\sim 0.02$ \\
\hline 2 & 0.2 & 9 & 900 & 4.626 & 23.8 & 148 & 31.4 & 24.5 & 34.6 & 84.0 & 8.3 & $\sim 0.04$ \\
\hline 3 & 0.5 & 9 & 900 & 4.626 & 24.0 & 144 & 29.3 & 21.2 & 26.1 & 90.0 & 7.6 & $\sim 0.10$ \\
\hline 4 & 1 & 9 & 900 & 4.625 & 24.1 & 146 & 27.2 & 19.3 & 22.0 & 90.4 & 7.3 & 23.3 \\
\hline 5 & 2 & 9 & 900 & 4.624 & 24.3 & 144 & 23.1 & 16.1 & 19.9 & 92.1 & 7.0 & 64.3 \\
\hline 6 & 0.2 & 10 & 900 & 4.951 & 24.5 & 122 & 23.8 & 16.8 & 21.0 & 92.0 & 7.6 & $\sim 0.04$ \\
\hline 7 & 0.2 & 11 & 900 & 4.541 & 24.7 & 101 & 22.0 & 14.1 & 18.9 & 92.8 & 6.6 & $\sim 0.04$ \\
\hline 8 & 0.2 & 9 & 1800 & 4.626 & 24.7 & 128 & 35.6 & 25.0 & 28.7 & 83.0 & 6.9 & $\sim 0.04$ \\
\hline 9 & 0.2 & 9 & 3600 & 4.626 & 24.8 & 110 & 41.0 & 30.8 & 41.7 & 88.3 & 6.0 & $\sim 0.04$ \\
\hline
\end{tabular}

${ }^{\text {a }}$ After drying, without crystal washing on the filter.

Average concentration of zinc(II) and chloride ions in the mother solution $\left[\mathrm{Zn}^{2+}\right]_{\mathrm{ML}}<0.5 \mathrm{mg} \mathrm{kg}^{-1} ;\left[\mathrm{Cl}^{-}\right]_{\mathrm{ML}}=0.76$ mass \%

Content of chloride ions in the solid product: $0.2-0.3$ mass $\%$

$\mathrm{L}_{\mathrm{m}}-$ mean crystal size, $\mathrm{L}_{\mathrm{m}}=\Sigma \mathrm{x}_{\mathrm{i}} \mathrm{L}_{\mathrm{i}}$, where: $\mathrm{x}_{\mathrm{i}}-$ mass fraction of crystals of mean fraction size $\mathrm{L}_{\mathrm{i}} ; \mathrm{L}_{50}-$ median crystal size for 50 mass $\%$ undersize fraction; $\mathrm{L}_{\mathrm{d}}-$ crystal mode size; $\mathrm{CV}=100\left(\mathrm{~L}_{84}-\mathrm{L}_{16}\right) /\left(2 \mathrm{~L}_{50}\right)$, where: $\mathrm{L}_{84}, \mathrm{~L}_{16}, \mathrm{~L}_{50}-$ crystal sizes corresponding to 84,16 and 50 mass

$\%$ undersize fractions in the cumulative distribution.

$\mathrm{SI}$ - saturation index, $\mathrm{SI}=\log (\mathrm{IAP})-\log \left(\mathrm{K}_{\mathrm{sp}}\right)$; IAP - ion activity product; SI values provided by Visual MINTEQ software 

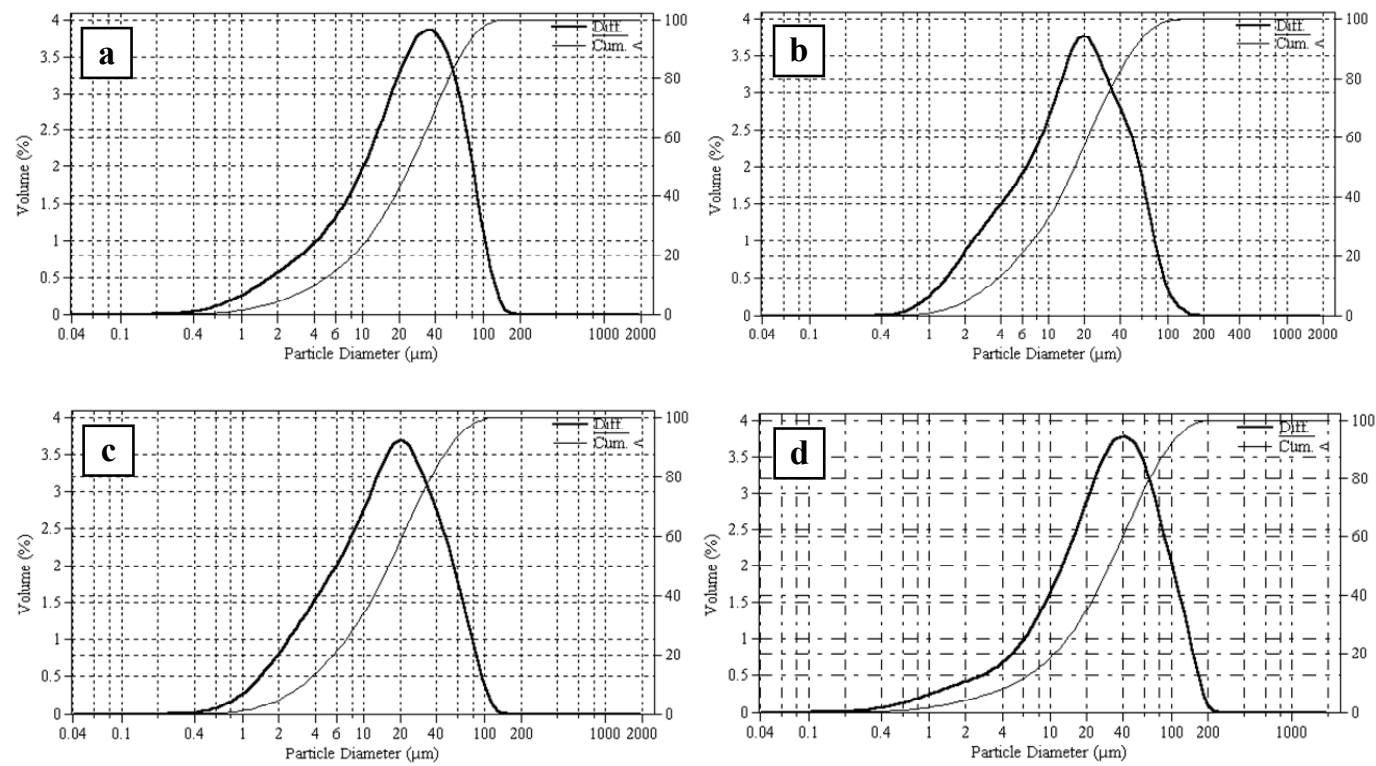

Figure 2: Exemplary differential (left scale) and cumulative (right scale) volumetric (mass) size distributions of struvite crystals produced in the continuous DT MSMPR crystallizer. Process parameters: (a) $\left[\mathrm{Zn}^{2+}\right]_{\mathrm{RM}} 0.2 \mathrm{mg} \mathrm{kg}^{-1}$, $\mathrm{pH} 9, \tau 900 \mathrm{~s}$; (b) $\left[\mathrm{Zn}^{2+}\right]_{\mathrm{RM}} 2.0 \mathrm{mg} \mathrm{kg}{ }^{-1}, \mathrm{pH} 9, \tau 900 \mathrm{~s}$; (c) $\left[\mathrm{Zn}^{2+}\right]_{\mathrm{RM}} 0.2 \mathrm{mg} \mathrm{kg}{ }^{-1}, \mathrm{pH} \mathrm{11, \tau} 900 \mathrm{~s}$; (d) $\left[\mathrm{Zn}^{2+}\right]_{\mathrm{RM}} 0.2 \mathrm{mg}$ $\mathrm{kg}^{-1}, \mathrm{pH}$ 9, $\tau 3600 \mathrm{~s}$ (tests No. 2, 5, 7 and 9 in Table 1).
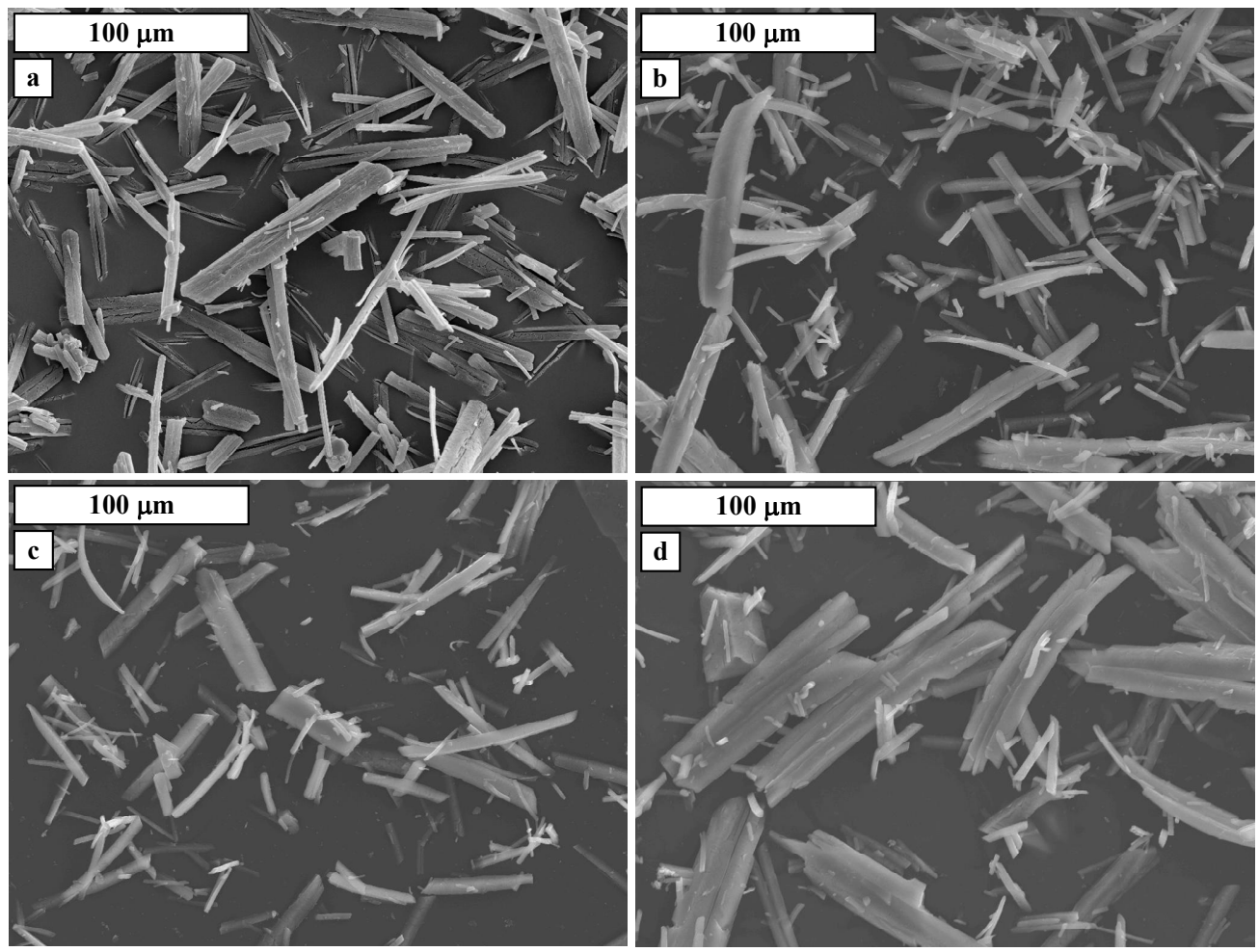

Figure 3: Scanning electron microscope images of struvite crystals produced in the continuous DT MSMPR crystallizer. Mean size of product crystals $\mathrm{L}_{\mathrm{m}}$ : (a) $31.4 \mu \mathrm{m}$; (b) $23.1 \mu \mathrm{m}$; (c) $22.0 \mu \mathrm{m}$; (d) $41.0 \mu \mathrm{m}$ (crystal size distributions - see Figure 2; tests No. 2, 5, 7 and 9 in Table 1). 
An increase in $\mathrm{pH}$ from 9 to $11\left(\left[\mathrm{Zn}^{2+}\right]_{\mathrm{RM}} 0.2 \mathrm{mg}\right.$ $\mathrm{kg}^{-1}, \tau 900 \mathrm{~s}$ ) caused the mean crystal size $\mathrm{L}_{\mathrm{m}}$ to decrease by $30 \%$ : from 31.4 to $22.0 \mu \mathrm{m}$. The $\mathrm{pH}$ increase in a struvite reaction crystallization system did not favour homogeneity within the product crystals population, as well. The CV coefficient increased from 84.0 to $92.8 \%$. The dominant crystal size $\mathrm{L}_{\mathrm{d}}$ shifted distinctly towards smaller values: from 34.6 $\mu \mathrm{m}(\mathrm{pH} 9)$ to $18.9 \mu \mathrm{m}(\mathrm{pH} 11)$. Both the number and size of the largest struvite product crystals decreased significantly. At pH 9 the largest size was ca. $160 \mu \mathrm{m}$ (Figure 2(a)), while at pH 11 was only ca. $110 \mu \mathrm{m}$ (Figure 2(c)). Simultaneously the smallest size fraction increased. At $\mathrm{pH} 9$ crystal fraction of sizes below $5 \mu \mathrm{m}$ in a product population represented $12.3 \%$, whereas at $\mathrm{pH} 11$ it increased up to $17.4 \%$. As a result, mean crystal size $\mathrm{L}_{\mathrm{m}}$ decreased by ca. $10 \mu \mathrm{m}$. In Figure 3(c) a scanning electron microscope image of product crystals is shown and the corresponding size distribution is presented in Figure 2(c). The smaller sizes of struvite crystals produced at $\mathrm{pH} 11$ are distinctly observable (compare Figure 3(a) and (c)).

Elongation of the mean residence time of the suspension in the crystallizer up to $3600 \mathrm{~s}$ resulted in an enlargement of product crystal sizes by more than $30 \%$ (tests No. 2, 8 and 9 in Table 1). In the presence of $0.2 \mathrm{mg} \mathrm{Zn}^{2+} \mathrm{kg}^{-1}$ in the feed, struvite crystals reached a mean size of $\mathrm{L}_{\mathrm{m}} 41 \mu \mathrm{m}(\mathrm{pH} 9, \tau 3600 \mathrm{~s})$. Elongation of the mean residence time of the suspension in the crystallizer working volume results in a decrease of the supersaturation in solution. As a consequence, both process kinetic components - the nucleation rate and the crystal linear growth rate decrease. A longer mean residence time of the crystal suspension in supersaturated mother liquor has, however, an advantageous final net effect on the process. Struvite crystals grew slower, longer and more stable, reaching thus larger sizes. However, homogeneity within the population $(\mathrm{CV} 84.0 \rightarrow 88.3 \%$ ) decreased. This can be explained by the effects of more intense attrition and breakage of crystals with the elongation of the residence time in a mixed and circulated suspension. Elongation of the mean residence time up to $3600 \mathrm{~s}$ shifted the dominant size $\mathrm{L}_{\mathrm{d}}$ of struvite crystals towards larger values: from $34.6 \mu \mathrm{m}(\tau 900 \mathrm{~s})$ up to $41.7 \mu \mathrm{m}(\tau 3600 \mathrm{~s})$. The largest crystal sizes in the whole product population reached ca. $160 \mu \mathrm{m}(\tau 900 \mathrm{~s}$, Figure 2(a)) and ca. $210 \mu \mathrm{m}(\tau$ $3600 \mathrm{~s}$, Figure 2(d)). On the contrary, the fraction of the smallest crystals decreased. Particles of size below $5 \mu \mathrm{m}$ in the product represented: 12.3 and $9.8 \%$, appropriately. The scanning electron microscope image of the product manufactured at $\tau 3600 \mathrm{~s}$ is presented in Figure 3(d). It is visible that number of small-size crystals decreased and one can distinguish characteristic tubular-shaped crystals, with deformed edges and some surface defects.

The influence of selected impurities (previous authors' studies) on the characteristics of struvite crystals produced in the continuous reaction crystallization process was compared in Table 2.

Table 2: Comparison of the influence of selected impurities present in the solution feeding the continuous DT MSMPR crystallizer on the struvite crystal characteristics. Process parameters: concentration of phosphate(V) ions in the feed: $\left[\mathrm{PO}_{4}{ }^{3-}\right]_{\mathrm{RM}}=1.0$ mass $\%$, molar proportions of substrate ions in the feed $\mathrm{PO}_{4}{ }^{3-}: \mathrm{Mg}^{2+}: \mathrm{NH}_{4}{ }^{+}=1: 1: 1$, mean residence time of the suspension in the crystallizer: $\tau 900 \mathrm{~s}, \mathrm{pH} 9$.

\begin{tabular}{|c|c|c|c|c|c|c|c|c|}
\hline \multicolumn{3}{|c|}{ Impurities in a feed } & \multicolumn{4}{|c|}{ Parameters of struvite CSD ${ }^{\mathrm{a}}$} & \multirow{2}{*}{$\frac{\text { Crystal shape }}{\mathbf{L}_{\mathbf{a}} / \mathbf{L}_{\mathbf{b}}}$} & \multirow[b]{2}{*}{ References } \\
\hline Ion & $\begin{array}{c}\text { Concentration } \\
\left(\mathrm{mg} \mathrm{kg} \mathrm{k}^{-1}\right)\end{array}$ & SI & $\begin{array}{c}\mathbf{L}_{\mathrm{m}} \\
(\mu \mathrm{m})\end{array}$ & $\begin{array}{c}\mathbf{L}_{50} \\
(\mu \mathrm{m})\end{array}$ & $\begin{array}{c}\mathbf{L}_{d} \\
(\mu \mathbf{m})\end{array}$ & $\begin{array}{l}\text { CV } \\
(\%)\end{array}$ & & \\
\hline $\mathrm{Ca}^{2+}$ & 500 & 4.593 & 32.6 & 25.5 & 27.8 & 85.1 & 4.2 & Hutnik et al., 2011b \\
\hline $\mathrm{Cu}^{2+}$ & 0.2 & 4.626 & 27.5 & 19.4 & 25.5 & 92.9 & 6.6 & Hutnik et al., 2011c \\
\hline $\mathrm{Fe}^{2+}$ & 5 & 4.626 & 33.0 & 27.4 & 24.6 & 81.8 & 5.0 & Hutnik et al., 2012 \\
\hline $\mathrm{K}^{+}$ & 250 & 4.624 & 31.6 & 25.0 & 25.6 & 83.0 & 5.3 & Hutnik et al., 2013b \\
\hline $\mathrm{NO}_{3}^{-}$ & 886 & 4.623 & 29.4 & 20.3 & 27.6 & 88.5 & 6.4 & Hutnik et al., 2013c \\
\hline $\mathrm{Zn}^{2+}$ & 0.2 & 4.626 & 31.4 & 24.5 & 34.6 & 84.0 & 8.3 & Present study \\
\hline $\mathrm{Zn}^{2+}$ & 2 & 4.624 & 23.1 & 16.1 & 19.9 & 92.1 & 7.0 & Present study \\
\hline $\mathrm{IWW}^{\mathrm{b}}$ & $*$ & 3.788 & 25.5 & 21.6 & 22.5 & 79.8 & 3.8 & Hutnik et al., 2013a \\
\hline $\mathrm{WI}^{\mathrm{c}}$ & - & 4.625 & 27.5 & 21.5 & 23.6 & 82.4 & 6.0 & Hutnik et al., 2011a \\
\hline
\end{tabular}

${ }^{\text {a }}$ Comments - see Table 1

${ }^{\mathrm{b}}$ Phosphorus fertilizer industry wastewater

${ }^{\mathrm{c}}$ Without impurities

* Concentration of phosphate(V) ions 0.445 mass \% and impurities (in $\mathrm{mg} \mathrm{kg}^{-1}$ ): $\mathrm{Al}-6.4, \mathrm{Ca}-440, \mathrm{Cu}-0.25, \mathrm{Fe}-8.9, \mathrm{~K}-46, \mathrm{Ti}-0.2$,

$\mathrm{Zn}-2.2, \mathrm{Si}-51, \mathrm{~F}^{-}-42, \mathrm{SO}_{4}{ }^{2-}-703$ (Hutnik et al., 2013a) 
All research was performed in the same DT MSMPR crystallizer (see Figure 1) with identical technological parameters $\left(\left[\mathrm{PO}_{4}^{3}\right]_{\mathrm{RM}} 1.0\right.$ mass $\%$, molar proportion of substrates in the feed: $\mathrm{PO}_{4}{ }^{3-}: \mathrm{Mg}^{2+}$ : $\left.\mathrm{NH}_{4}{ }^{+}=1: 1: 1, \mathrm{pH} \mathrm{9, \tau} 900 \mathrm{~s}\right)$. The concentrations of the ionic impurities were chosen as typical values for selected industrial and agricultural wastewaters. The characteristics of struvite crystals produced from real wastewater from the phosphorus mineral fertilizer industry (IWW) were also provided (Hutnik et al., 2013a). Size distribution parameters of struvite crystals manufactured from "pure" aqueous solutions of $\mathrm{PO}_{4}^{3-}, \mathrm{Mg}^{2+}$ and $\mathrm{NH}_{4}{ }^{+}$ions without impurities (WI) were used as the reference data. From the comparison, the individual impurities clearly influenced the size characteristics, population homogeneity and shape of struvite crystals. From the individually assumed concentration of each impurity in the crystallizer feed (Table 2) their individual influence on the product crystal size distribution parameters $\left(\mathrm{L}_{\mathrm{m}}, \mathrm{L}_{50}\right.$, $\mathrm{L}_{\mathrm{d}}$ ) was generally regarded to be advantageous.

The largest mean size $\mathrm{L}_{\mathrm{m}}$ of struvite crystals corresponded to the presence of $5 \mathrm{mg} \mathrm{Fe} \mathrm{kg}^{-1}: 33.0 \mu \mathrm{m}$ (from solution WI: $\mathrm{L}_{\mathrm{m}} 27.5 \mu \mathrm{m}$ ). The impurities presented in Table 2 caused the mean size $\mathrm{L}_{\mathrm{m}}$ of struvite crystals to increase by ca. $12 \%$ on average (maximally by $20 \%$ ). Homogeneity within the product crystals was generally lower. The coefficient of crystal size variation $\mathrm{CV}$ reached $92.9 \%\left(0.2 \mathrm{mg} \mathrm{Cu}^{2+} \mathrm{kg}^{-1}\right)$ compared to CV $82.4 \%$ (WI). The presence of impurities thus resulted in higher diversification of crystal sizes, by ca. $6 \%$ in average (maximally by ca. $13 \%$ ). In the case of real industrial wastewater (IWW) containing 0.445 mass \% of phosphate(V) ions coupled with a set of various impurities (aluminum, calcium, copper, iron, potassium, titanium, zinc, silicate, fluoride, sulphate(VI) ions) the crystals obtained in a continuous DT MSMPR crystallizer had mean size $\mathrm{L}_{\mathrm{m}} 25.5 \mu \mathrm{m}$ and CV 79.8\% (Hutnik et al., 2013a). These were thus crystals of smaller sizes, however slightly more homogeneous compared to struvite produced from the pure aqueous solution of $\mathrm{PO}_{4}{ }^{3-}$, $\mathrm{Mg}^{2+}$ and $\mathrm{NH}_{4}^{+}$ions (WI): $\mathrm{L}_{\mathrm{m}} 27.5 \mu \mathrm{m}, \mathrm{CV} 82.4 \%$. None of the effects of industrial impurities present in real wastewater on struvite CSD turned out to be generally disadvantageous.

It should be noted that, although with the increase in zinc(II) ions concentration in the feed, the mean size of struvite crystals decreases (Table 1); a smaller concentration of these ions (from 0.1 to $0.5 \mathrm{mg} \mathrm{Zn}^{2+}$ $\mathrm{kg}^{-1}$ ) favors manufacture of crystals of larger sizes $\left(\mathrm{L}_{\mathrm{m}} 34.0 \rightarrow 29.3 \mu \mathrm{m}\right)$ compared to WI solutions $\left(\mathrm{L}_{\mathrm{m}}\right.$ $27.5 \mu \mathrm{m})$ (Table 2). Smaller amount of zinc(II) ions in the reaction crystallization system confines struvite nucleation and advantageously affects its crystals growth. On the contrary, a higher concentration of zinc(II) ions (1-2 $\mathrm{mg} \mathrm{Zn}^{2+} \mathrm{kg}^{-1}$ ) catalyzes struvite nucleation, thus producing smaller final crystal sizes and higher size diversification (CV even 92.1\%).

\section{Crystal Shape}

The best shaped struvite crystals were produced at low $\mathrm{pH}$, with elongated mean residence time of the suspension in the crystallizer and at low concentration of zinc(II) ions in the process system (see Figure 3(d)). The mean size of these crystals was $L_{m} 41.0$ $\mu \mathrm{m}$ and CV ca. $88.3 \%$ (test No. 9 in Table 1, Figure 2(d)). The crystal length $L_{a}$ to width $L_{b}$ ratio was 6.0 on average. The $L_{a} / L_{b}$ ratios were calculated from planimetric measurements covering 50 crystals randomly selected from three different scanning electron microscope images of the same product sample. This amount is satisfactory to provide rough information about observed trends in crystal habit modification. From the measurements, for all product crystals the $\mathrm{L}_{\mathrm{a}} / \mathrm{L}_{\mathrm{b}}$ varied generally within the $6.0-8.4$ range. The thinnest crystals $\left(\mathrm{L}_{a} / \mathrm{L}_{b} 8.3-8.4\right)$ correspond to a low concentration of zinc(II) ions in the feed $\left(0.1-0.2 \mathrm{mg} \mathrm{Zn}{ }^{2+} \mathrm{kg}^{-1}, \mathrm{pH} 9\right.$ and $\tau 900 \mathrm{~s}$; see Figure 3(a)). With the increase in feed concentration of zinc(II) ions, the crystals become shorter, but their width $\mathrm{L}_{b}$ simultaneously increases $\left(\mathrm{L}_{\mathrm{a}} / \mathrm{L}_{\mathrm{b}} 7.0\right.$ for 2.0 $\mathrm{mg} \mathrm{Zn}^{2+} \mathrm{kg}^{-1}$; Figure 3(b)). An increase in $\mathrm{pH}$ produces a decrease of crystal length $L_{a}$ but their width $\mathrm{L}_{\mathrm{b}}$ practically unmodified $\left(\mathrm{L}_{\mathrm{a}} / \mathrm{L}_{\mathrm{b}} 6.6\right.$ at $\mathrm{pH} 11$; Figure 3(c)). Elongation of the mean residence time of the suspension in the crystallizer up to $3600 \mathrm{~s}$ influences crystal shape advantageously. Crystals become simultaneously both longer and wider $\left(\mathrm{L}_{\mathrm{a}} / \mathrm{L}_{\mathrm{b}} 6.0\right.$; Figure $3(d)) . L_{a} / L_{b}=6.0$ is a characteristic value for the typical shape of struvite crystals produced from phosphate(V) solutions without impurities (see Table 2; WI). The detailed influence of selected ionic impurities on intrinsic struvite crystals geometry is presented in Table 2. From this comparison, individual impurities modify significantly not only crystal sizes, but also their shape, represented by $\mathrm{L}_{\mathrm{a}} / \mathrm{L}_{\mathrm{b}}$ : from 3.8

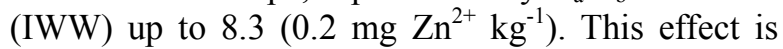
especially spectacular for struvite recovered from phosphorus mineral fertilizer industry wastewater (Hutnik et al., 2013a). These crystals were shorter and simultaneously thicker $\left(\mathrm{L}_{\mathrm{a}} / \mathrm{L}_{\mathrm{b}} 3.8\right)$. Their surface was partly occupied by various chemical forms of co-precipitated and co-crystallized impurities. This also generated large tensions within such crystal 
structures (cracks, through-like crystal forms, etc.). Analysis of scanning microscope images of the products (Figure 3) indicated that the geometrical shape of struvite crystals was diverse. Prismatic, needle-like particles and even tubular crystals with deformed, irregular edges were observed. In Figure 4 a magnified tubular crystal of struvite is presented (part of the image from Figure 3(d)).

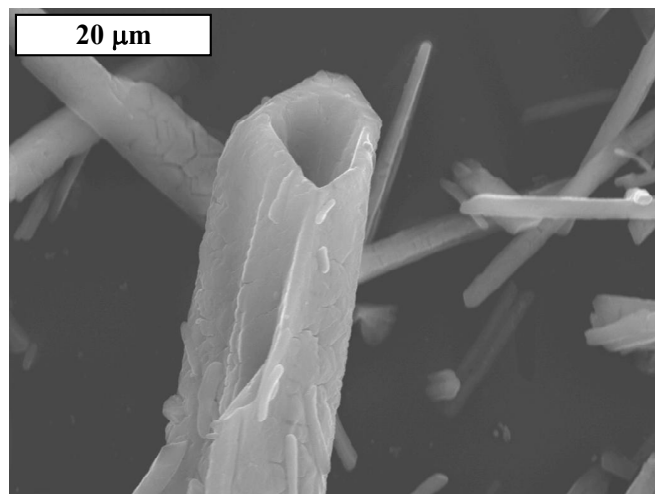

Figure 4: Details of habit and surface morphology of a struvite crystal produced in the presence of zinc(II) ions (corresponding to Figure 3(d)).

Surface defects within the crystal and some small solid particles adhered to its surface are visible. The volume shape factor $k_{v}\left(=V_{\text {crystal }} / \mathrm{L}^{3}\right)$ of these solids varied typically from 0.010 to 0.040 , for $\mathrm{L}_{\mathrm{a}}: \mathrm{L}_{\mathrm{b}}: \mathrm{L}_{\mathrm{c}}=$ $10: 1: 1$ and $5: 1: 1$, respectively (Mersmann, 1995). If the particles are elongated or needle-shaped, their volume may be calculated on the assumption that these are cylindrical (Mullin, 1993). Mean $\mathrm{k}_{\mathrm{v}}$ values calculated under this assumption were: $0.011(0.2 \mathrm{mg}$ $\mathrm{Zn}^{2+} \mathrm{kg}^{-1}$ in the feed, $\mathrm{pH} \mathrm{9, \tau} 900 \mathrm{~s}$; Figure 3(a)), $0.016\left(2.0 \mathrm{mg} \mathrm{Zn}^{2+} \mathrm{kg}^{-1}, \mathrm{pH} 9, \tau 900 \mathrm{~s}\right.$; Figure 3(b)), $0.018\left(0.2 \mathrm{mg} \mathrm{Zn}^{2+} \mathrm{kg}^{-1}, \mathrm{pH} 11, \tau 900 \mathrm{~s}\right.$; Figure 3(c)) and $0.022\left(0.2 \mathrm{mg} \mathrm{Zn}^{2+} \mathrm{kg}^{-1}\right.$, pH 9, $\tau 3600 \mathrm{~s}$; Figure 3(d)). Agglomeration effects were not significant, while attrition and breakage of crystals during their intensive mixing and circulation in the crystallizer can be regarded as moderate. Single broken crystals, surface damage, and partly destroyed corners can be observed. However, the number of such crystals is not large. Generally, then the process conditions established in a DT MSMPR crystallizer for the continuous nucleation and growth of struvite crystals are advantageous.

\section{Chemical Composition}

The concentration of phosphate $(\mathrm{V})$ ions in the postprocessed mother solution $\left[\mathrm{PO}_{4}{ }^{3-}\right]_{\mathrm{ML}}$ varied from $148 \mathrm{mg} \mathrm{PO}_{4}{ }^{3-} \mathrm{kg}^{-1}$ (pH 9, $\tau 900 \mathrm{~s}$ ) to $101 \mathrm{mg} \mathrm{PO}_{4}{ }^{3-} \mathrm{kg}^{-1}$
(pH 11, $\tau 900 \mathrm{~s}$ ), for $0.2 \mathrm{mg} \mathrm{Zn}^{2+} \mathrm{kg}^{-1}$ in a feed (Table 1). Zinc(II) ions, in the examined range of their concentration, practically did not influence the process yield. The concentration of phosphate $(\mathrm{V})$ ions in the postprocessed mother solution varied from 144 to $148 \mathrm{mg} \mathrm{PO}{ }_{4}^{3-} \mathrm{kg}^{-1}$ (average: ca. $146 \mathrm{mg} \mathrm{PO}_{4}{ }^{3-} \mathrm{kg}^{-1}$ ). However, with the increase in $\mathrm{pH}$ and enlargement of the mean residence time of the suspension in the crystallizer, these values systematically decreased to $101 \mathrm{mg} \mathrm{PO}{ }_{4}^{3-} \mathrm{kg}^{-1}$ (pH 11) and to $110 \mathrm{mg} \mathrm{PO}_{4}{ }^{3-} \mathrm{kg}^{-1}$ ( $\tau 3600 \mathrm{~s})(25$ to $30 \%$ decrement). This is attributed to the decrease of struvite solubility with the increase in $\mathrm{pH}$ and the longer contact time of crystals with the supersaturated solution (more thorough discharge of the supersaturation). The $\left[\mathrm{PO}_{4}{ }^{3-}\right]_{\mathrm{ML}}$ values can be generally considered small; thus, the effectiveness of phosphate $(\mathrm{V})$ ion removal from the feed (of $\left[\mathrm{PO}_{4}{ }^{3-}\right]_{\mathrm{RM}}$ 1.0 mass \%) is fully satisfactory: ca. $99 \%$.

The concentration of zinc(II) ions in the postprocessed mother solution did not exceed $0.5 \mathrm{mg} \mathrm{Zn}^{2+} \mathrm{kg}^{-1}$. For the feeds of concentration $\left[\mathrm{Zn}^{2+}\right]_{\mathrm{RM}} 0.1$ or $0.2 \mathrm{mg}$ $\mathrm{kg}^{-1}$, the concentration of zinc(II) ions in the liquid mixture after reaction crystallization of struvite was nearly the same as their initial feed concentration, namely 0.1 or $0.2 \mathrm{mg} \mathrm{Zn}^{2+} \mathrm{kg}^{-1}$ (tests No. 1 and 2 in Table 1). Co-precipitation and co-crystallization of zinc(II) hydroxide was practically not observed $\left(\mathrm{pK}_{\mathrm{sp}}\right.$ 15.5). The presence of zinc(II) in the crystal product was confirmed analytically in the amount of ca. 0.02 or $0.04 \mathrm{mg} \mathrm{Zn}^{2+} \mathrm{kg}^{-1}$. However, this amount of zinc(II) arises from adhered mother solution (since the solid product removed was not washed with water). Feeding the crystallizer with solution containing 1.0 or $2.0 \mathrm{mg} \mathrm{Zn} \mathrm{Zg}^{2+} \mathrm{kg}^{-1}$, it was observed that the majority of zinc(II) ions co-precipitated (as $\mathrm{Zn}(\mathrm{OH})_{2}$ ). The zinc(II) content in the product was considerably higher: 23.3 or $64.3 \mathrm{mg} \mathrm{Zn}^{2+} \mathrm{kg}^{-1}$, respectively (Table 1). The product also contained chloride ions present in mother liquor, derived from the feed (from dissolution in water of crystalline $\mathrm{MgCl}_{2} \cdot 2 \mathrm{H}_{2} \mathrm{O}$ and $\mathrm{ZnCl}_{2}$ ). The mean concentration of these ions in the mother solution was 0.76 mass \% (Table 1). After filtration (from 15 to 25 mass \% of the mother solution remained in the filtration cake) and after product drying, the chloride ion content varied from 0.2 to 0.3 mass \%. Chloride ions with sodium ions (from the alkalizing solution) form in the dry product crystalline halite $(\mathrm{NaCl})$. Zinc hydroxide and halite do not influence the fertilizer quality of the produced struvite advantageously (Rahman et al., 2014).

The presence of other impurity ions in wastewaters, especially calcium, iron and potassium ions influences not only the product's physical form (Table 2), but also its chemical composition. The sparingly 
soluble hydroxides of selected impurity metals (e.g. iron) co-precipitate and co-crystallize. During drying of the post-filtered product, potassium or/and sodium chlorides (sylvine, halite) co-crystallize. However, amorphous calcium phosphate $(\mathrm{V}) \mathrm{Ca}_{3}\left(\mathrm{PO}_{4}\right)_{2} \cdot \mathrm{nH}_{2} \mathrm{O}$ is mainly produced. Depending on the chemical composition of the wastewater, the solids produced from this wastewater can contain more amorphous phase (calcium phosphates, metal hydroxides) than the crystalline phase (struvite, halite, sylvine) (Kozik et al., 2014b). Chemical compositions of the products manufactured in the presence of impurities were presented in works of the authors cited in Table 2.

\section{CONCLUSIONS}

Struvite crystals of mean size $\mathrm{L}_{\mathrm{m}}$ from 22 to 41 $\mu \mathrm{m}$ were removed from the continuous DT MSMPR type crystallizer. With the increase in zinc(II) ion concentration in the feed from 0.1 to $2.0 \mathrm{mg} \mathrm{kg}^{-1}$, the mean product crystal size $\mathrm{L}_{\mathrm{m}}$ decreased by ca. $32 \%$ (from 34.0 to $23.1 \mu \mathrm{m}$ at $\mathrm{pH} 9$ and $\tau 900 \mathrm{~s}$ ). Homogeneity within the product crystal population decreased by more than $11 \%(\mathrm{CV} 82.7 \rightarrow 92.1 \%)$. An increase in $\mathrm{pH}$ of the struvite reaction crystallization environment influenced the product quality disadvantageously. Smaller crystals $\left(\mathrm{L}_{\mathrm{m}} 22 \mu \mathrm{m}\right.$ at $\mathrm{pH} 11$ and $0.2 \mathrm{mg} \mathrm{Zn}^{2+} \mathrm{kg}^{-1}$ in the feed) of lower homogeneity (CV 92.8\%) were produced. In contrast, an elongation of the mean residence time of the suspension in the crystallizer (up to $3600 \mathrm{~s}$ ) resulted in an increase in product crystal size by more than $30 \%$. Homogeneity of the crystal population was practically not improved. Based on scanning electron microscope images of product crystals, one can conclude that agglomeration effects were less than moderate. Properly shaped struvite crystals of $\mathrm{L}_{\mathrm{a}} / \mathrm{L}_{\mathrm{b}}$ from 8.4 to 6.0 were produced (corresponding to $\mathrm{k}_{\mathrm{v}} 0.011-0.022$ ).

Precipitation of phosphate $(\mathrm{V})$ ions in the presence of zinc(II) ions results in production not only of struvite crystals, but also zinc(II) hydroxide particles and halite $(\mathrm{NaCl})$ crystals. Impure product was thus obtained, which essentially decreases its market value. It also restricts its eventual application in agriculture. However, some mineral fertilizers are purposefully enriched in zinc(II), regarded as a microelement. The presence of zinc(II) ions also favored crystallization of struvite in the form of tubular crystals. These forms demonstrated some ruptures along the longitudinal axis and on the surface, as well as clearly rough edges. Removal of mother solution from the interior of such tubes is practically impossible during their filtration and washing. Zinc(II) content in the product varied from 0.02 to $64.3 \mathrm{mg} \mathrm{kg}^{-1}$ depending on the zinc(II) ion concentration in the feed and the process parameters applied. The concentration of these ions in the postprocessed mother solution did not exceed $0.5 \mathrm{mg} \mathrm{kg}^{-1}$. However, the concentration of phosphate $(\mathrm{V})$ ions in this solution decreased to ca. $100-$ $150 \mathrm{mg} \mathrm{kg}^{-1}$ depending on the process technological parameters, which can be regarded as a very good result for their removal from the feed solution.

\section{ACKNOWLEDGEMENT}

The work was supported by the National Science Centre of Poland (NCN) under grant No. NN209 095940 (2011-2014).

\section{NOMENCLATURE}

$\left[\mathrm{Cl}^{-}\right]_{\mathrm{ML}}$ concentration of chloride ions in the postprocessed mother solution

(mass \%)

$\mathrm{CV} \quad$ coefficient of crystal size variation (\%)

$\mathrm{d}_{\mathrm{dt}} \quad$ draft tube diameter $(\mathrm{m})$

$\mathrm{d}_{\mathrm{m}} \quad$ propeller stirrer diameter $(\mathrm{m})$

D crystallizer diameter $(\mathrm{m})$

$\mathrm{h}_{\mathrm{dt}} \quad$ draft tube height $(\mathrm{m})$

$\mathrm{H} \quad$ crystallizer height $(\mathrm{m})$

$\mathrm{k}_{\mathrm{v}} \quad$ crystal's volume shape factor

$\mathrm{K}_{\mathrm{sp}} \quad$ solubility product

L crystal characteristic size $(\mathrm{m})$

$\mathrm{L}_{50} \quad$ median crystal size for 50 mass $\%$ undersize fraction in the cumulative mass (volume) distribution (m)

$\mathrm{L}_{84}, \mathrm{~L}_{16} \quad$ crystal sizes corresponding to 84 and 16 mass \% undersize fractions in the cumulative mass (volume) distribution (m)

$\mathrm{L}_{\mathrm{a}} \quad$ crystal length (m)

$\mathrm{L}_{\mathrm{b}} \quad$ crystal width (m)

$\mathrm{L}_{\mathrm{c}} \quad$ crystal height $(\mathrm{m})$

$\mathrm{L}_{\mathrm{d}} \quad$ crystal mode size $(\mathrm{m})$

$\mathrm{L}_{\mathrm{i}} \quad$ mean size of the $i$-th fraction (m)

$\mathrm{L}_{\mathrm{m}} \quad$ mean crystal size $(\mathrm{m})$

$\mathrm{M}_{\mathrm{T}} \quad$ solid phase content in the product crystal suspension $\left(\mathrm{kg} \mathrm{m}^{-3}\right)$

$\left[\mathrm{PO}_{4}{ }^{3-}\right]_{\mathrm{ML}}$ concentration of phosphate $(\mathrm{V})$ ions in the postprocessed mother solution (mass \%)

$\left[\mathrm{PO}_{4}{ }^{3-}\right]_{\mathrm{RM}}$ feed concentration of phosphate(V) ions (mass \%)

$\mathrm{x}_{\mathrm{i}} \quad$ mass fraction of crystals

$\mathrm{V}_{\text {crystal }} \quad$ crystal volume $\left(\mathrm{m}^{3}\right)$ 
$\left[\mathrm{Zn}^{2+}\right]_{\mathrm{ML}}$ concentration of zinc(II) ions in the postprocessed mother solution $\left(\mathrm{mg} \mathrm{kg}^{-1}\right)$

$\left[\mathrm{Zn}^{2+}\right]_{\mathrm{RM}}$ feed concentration of zinc(II) ions $\left(\mathrm{mg} \mathrm{kg}^{-1}\right)$

\section{Greek Letters}

$\tau \quad$ mean residence time of the crystal suspension (s)

\section{Abbreviations}

$\begin{array}{ll}\text { CSD } & \text { Crystal Size Distribution } \\ \text { DT } & \text { Draft Tube } \\ \text { IAP } & \text { Ion Activity Product } \\ \text { IWW } & \text { Industrial Wastewater } \\ \text { MSMPR } & \text { Mixed Suspension Mixed Product } \\ & \text { Removal crystallizer } \\ \text { SI } & \text { Saturation Index } \\ \text { WI } & \text { Without Impurities }\end{array}$

\section{REFERENCES}

Ali, Md. I. and Schneider, P. A., A Fed-batch design approach of struvite system in controlled supersaturation. Chemical Engineering Science, 61, 3951 (2006).

Bhuiyan, M. I. H., Mavinic, D. S. and Beckie, R. D., A solubility and thermodynamic study of struvite. Environmental Technology, 28, 1015 (2007).

Bhuiyan, M. I. H., Mavinic, D. S. and Koch, F. A., Phosphorus recovery from wastewater through struvite formation in fluidized bed reactors: A sustainable approach. Water Science and Technology, 57, 175 (2008).

Bouropoulos, N. C. and Koutsoukos, P. G., Spontaneous precipitation of struvite from aqueous solutions. Journal of Crystal Growth, 213, 381 (2000).

de-Bashan, L. E. and Bashan, Y., Recent advances in removing phosphorus from wastewater and its future use as fertilizer. Water Research, 38, 4222 (2004).

Doyle, J. D. and Parsons, S. A., Struvite formation, control and recovery. Water Research, 36, 3925 (2002).

Doyle, J. D. and Parsons, S. A., Struvite scale formation and control. Water Science and Technology, 49, 177 (2004).

Gustafsson, J. P., Visual MINTEQ ver.3.1, 2014. $<\mathrm{http}$ ://vminteq.lwr.kth.se/>

Hutnik, N., Piotrowski, K., Gluzinska, J. and Matynia, A., Effect of selected inorganic impurities present in real phosphate(V) solutions on the quality of struvite crystals produced in continuous reaction crystallization process. Progress in Environmental Science and Technology, 3, 559 (2011a).

Hutnik, N., Piotrowski, K., Wierzbowska, B. and Matynia, A., Continuous reaction crystallization of struvite from phosphate(V) solutions containing calcium ions. Crystal Research and Technology, 46, 443 (2011b).

Hutnik, N., Matynia, A., Piotrowski, K. and Mazienczuk, A., Influence of copper(II) ions on the quality of struvite crystals produced in continuous reaction crystallization process. Markos, J., (Ed.), Proceedings of the $38^{\text {th }}$ International Conference of Slovak Society of Chemical Engineering, Slovakia, 318 (2011c).

Hutnik, N., Piotrowski, K., Wierzbowska, B. and Matynia, A., Continuous reaction crystallization of struvite from water solutions of phosphates $(\mathrm{V})$ in presence of iron(II) ions. Journal of Environmental Science and Engineering, A1, 35 (2012).

Hutnik, N., Wierzbowska, B. and Matynia, A., Continuous reaction crystallization of struvite from solution containing phosphate $(\mathrm{V})$ and potassium ions. Przemysł Chemiczny, 92, 791 (2013b).

Hutnik, N., Wierzbowska, B., Piotrowski, K. and Matynia, A., Continuous reaction crystallization of struvite from solution containing phosphate $(\mathrm{V})$ and nitrate ions. The Online Journal of Science and Technology, 3, 58 (2013c).

Hutnik, N., Kozik, A., Mazienczuk, A., Piotrowski, K., Wierzbowska, B. and Matynia, A., Phosphates(V) recovery from phosphorus mineral fertilizers industry wastewater by continuous struvite reaction crystallization process. Water Research, 47, 3635 (2013a).

Karabegovic, L., Uldal, M., Werker, A. and MorganSagastume, F., Phosphorus recovery potential from a waste stream with high organic and nutrient contents via struvite precipitation. Environmental Technology, 34, 871 (2013).

Kofina, A. N. and Koutsoukos, P. G., Spontaneous precipitation of struvite from synthetic wastewater solutions. Crystal Growth and Design, 5, 489 (2005).

Kozik, A., Hutnik, N., Piotrowski, K., Mazienczuk, A. and Matynia, A., Precipitation and crystallization of struvite from synthetic wastewater under stoichiometric conditions. Advances in Chemical Engineering and Science, 3, 20 (2013).

Kozik, A., Hutnik, N., Piotrowski, K. and Matynia, A., Continuous reaction crystallization of struvite from diluted aqueous solution of phosphate(V) ions in the presence of magnesium ions excess. 
Chemical Engineering Research and Design, 92, 481 (2014a).

Kozik, A., Hutnik, N., Podworny, J., Gerle, A., Mazienczuk, A. and Matynia, A., Recovery of phosphate(V) ions from synthetic swine wastewater under stoichiometric conditions. Przemysl Chemiczny, 93, 559 (2014b).

Latifian, M., Liu, J. and Mattiasson, B., Struvitebased fertilizer and its physical and chemical properties. Environmental Technology, 33, 2691 (2012).

Le Corre, K. S., Valsami-Jones, E., Hobbs, P. and Parsons, S. A., Impact of calcium on struvite crystal size, shape and purity. Journal of Crystal Growth, 283, 514 (2005).

Le Corre, K. S., Valsami-Jones, E., Hobbs, P. and Parsons, S. A., Impact of reactor operation on success of struvite precipitation from synthetic liquors. Environmental Technology, 28, 1245 (2007a).

Le Corre, K. S., Valsami-Jones, E., Hobbs, P. and Parsons, S. A., Kinetics of struvite precipitation: Effect of magnesium dose on induction times and precipitation rates. Environmental Technology, 28, 1317 (2007b).

Le Corre, K. S., Valsami-Jones, E., Hobbs, P. and Parsons, S. A., Phosphorus recovery from wastewater by struvite crystallization: A review. Critical Reviews in Environmental Science and Technology, 39, 433 (2009).

Marti, N., Pastor, L., Bouzas, A., Ferrer, J. and Seco,
A., Phosphorus recovery by struvite crystallization in WWTPs: Influence of the sludge treatment line operation. Water Research, 44, 2371 (2010).

Matynia, A., Koralewska, J., Piotrowski, K. and Wierzbowska, B., The influence of the process parameters on the struvite continuous crystallization kinetics. Chemical Engineering Communications, 193, 160 (2006).

Mazienczuk, A., Hutnik, N., Piotrowski, K., Wierzbowska, B. and Matynia, A., Continuous crystallizers with jet pump driven by recirculated mother solution in production of struvite. Przemysł Chemiczny, 91, 890 (2012).

Mersmann, A., (Ed.), Crystallization Technology Handbook. M. Dekker, Inc., New York (1995).

Mullin, J. W., Crystallization. Butterworth-Heinemann, Oxford (1993).

Ohlinger, K. N., Young, T. M. and Schroeder, E. D., Predicting struvite formation in digestion. Water Research, 32, 3607 (1998).

Parsons, S. A., Recent scientific and technical developments: Struvite precipitation. CEEP Scope Newsletter, 41, 15 (2001).

Rahman, M. M., Salleh, M. A. M., Rashid, K., Ahsan, A., Hossain, M. M. and Ra, C. S., Production of slow release crystal fertilizer from wastewaters through struvite crystallization - a review. Arabian Journal of Chemistry, 7, 139 (2014).

Snoeyink, V. L. and Jenkins, D., Water Chemistry. Wiley, New York (1980). 